\title{
The effect of co-creation experience on outcome variable
}

Annals of Tourism Research

Volume 57, March 2016, Pages 62-75

\author{
Elaine F. Mathis, \\ Hyelin (Lina) Kim, \\ Muzaffer Uysal, \\ Joseph M. Sirgy, \\ Nina K Prebensen
}

\begin{abstract}
This study examines the underlying dimensions of co-creation of an experience in the context of tourism and its effects on behavioral consequences such as tourists' satisfaction with the co-creation of an experience, subjective well-being, and loyalty to the service provider. The purpose of the study is achieved by showing that that tourists' co-creation of an experience positively affects the vacation experience and loyalty to the service provider. In turn, satisfaction with the vacation experience influences overall life satisfaction. The results of this study should help service providers change strategies and implement a platform for creating unique co-creation of experiences, allowing tourists to become more physically and emotionally engaged in the planning of their vacations.
\end{abstract}




\section{Introduction}

The concept of co-creation of an experience focuses on the idea of the customer as a creator of value, interacting with the organization to "co-create" value (Prebensen, Vittersø, \& Dahl, 2013). The concept originally stems from the service-dominant logic proposed by Vargo and Lusch (2008). In contrast to goods-dominant logic, servicedominant logic is focused on the exchange of service. Under service-dominant logic, a service is exchanged for another service as parties contribute to the creation process by sharing knowledge and resources. Through this interaction a more beneficial service is co- produced, and value is added, given that resources are shared by both parties. Vargo and Lusch (2008) argued that the customer is always a co-creator of value. Furthermore, "value creation is always inter- actional and that together, the supplier and customers have the opportunity to create value through customized, co-produced, offerings," (Payne, Storbacka, \& Frow, 2008, p. 96). In a tourism setting, while participating in the co-creation of an experience, the tourist brings in various types of personal resources such as time, effort, money, and knowledge. Through interactions and assistance by the ser- vice provider, value is created-the tourist then becomes part producer as opposed to a mere con- sumer. The more the tourist is engaged in the co-creation process through time and effort, the more likely he or she is to gain a positive experience (Prebensen, Woo, Chen, \& Uysal, 2013). The con- vergence of activities between supplier and producer create a method of co-creation that guarantees the delivery of "unique" value to customers, as no two customers will ever experience the same added-valuegiven that every interaction is different (Cova, Dalli, \& Zwick, 2011).

Research on the co-creation of an experience has recently been receiving a significant amount of attention in marketing and tourism research (e.g., Shaw, Bailey, \& Williams, 2011; Verhoef, Reinartz, \& Krafft, 2010). Researchers have primarily focused on the antecedents influencing the co-creation of an experience (e.g., Cova et al., 2011; Lee, 2012; Zhang \& Chen, 2008). Research has also focused on how, and why, customers participate in the co-creation process and identifying customers' thoughts and feelings about the process (e.g., Cabiddu, Lui, \& Piccoli, 2013; Kristensson, Matthing, \& Johansson, 2008; Prahalad \& Ramaswamy, 2004).

In this vein, the purpose of this study is to examine the underlying dimensions of the construct of co-creation of an experience in the context of tourism and its effects on behavioral consequences such as satisfaction with the vacation experience, overall life satisfaction, and loyalty to the service provider. The results of this study may help tourism service providers establish programs and policies supporting co-creation of an experience.

\section{Literature review}

In this section, the following questions will be addressed: How is value created and what is co-creation of an experience. How does co-creation of an experience affect satisfaction with the vacation experience and satisfaction with life overall? How does satisfaction with the vacation experience affect customer loyalty? And lastly, what is the role of the tourist's involvement?

The concept of co-creation of an experience

Delivering the quality of an experience to customers has been one of the key elements for success- ful marketing strategy (Prebensen, Chen, \& Uysal, 2014). In a tourism context, the tourist experience is considered as "an individual perception generated in the context of interactions and resource integra- tion" (Bjork \& Sfandla, 2009). The element of 
experience involves the tourist emotionally, physically, spiritually, and intellectually (Prebensen et al., 2014). Recent studies argue that tourists are gaining more power and control over what goes into the nature of tourism products as experiences with which tourists also construct their own narratives (Binkhorst \& Dekker, 2009). This construction of narratives may be influenced by the extent to which the interaction takes place between tourists and the setting, as well as the interaction between local residents and fellow tourists. The nature of this interaction provides the core of tourists' experiences (Walls \& Wang, 2001). Values related to the co-creation of an experience become an integrated process between tourists and service providers or the setting. Co-creating value in tourism experiences focuses greatly on the role of tourists and settings (or service providers). Grönroos defines value creation as "the customer's creation of value-in-use," (Grönroos, 2011, p. 282). Others believe that, "there can be no value without the customer incorporat- ing the firm offering into his or her life" (Grönroos, 2011, p. 287). This indicates that value is created by the user, who is also the one to experience the added value; therefore, the user determines what and how much value is created. As customers are increasingly gaining power and control, service providers today need to interact with them actively. Prahalad and Ramaswamy (2004) argue for the co-creation of experiences to serve as a basis for value and also as the future of innovation. Vargo and Lusch (2008) believe that value co-creation suggests that "there is no value until an offering is used-experience and perception are essential to value determination" (Vargo, Maglio, \& Akaka, 2008, p. 148). These quota- tions indicate that for co-creation of experiences to take place both the tourist and the service provider must be involved and cooperatively work together to create a better service offering. $\mathrm{Co}^{-}$ creation of experiences is about the process through which customers interact with service providers, or settings, to create their own unique experience. For example, the Dutch Fletcher hotel in the Netherlands strives to have customers' insights and options by conducting online surveys to get input from customers. These surveys are then reviewed and used by the organization to make changes to better satisfy guest desires and suggestions.

With the concept of co-creation of an experience, and a greater focus on the customer than on the service, marketing organizations have moved from a goods-dominant approach to a service-dominant approach. The new dominant logic for marketing is service-based logic, which is commonly referred to as "service logic" (Grönroos, 2011). It is tied to the value-in-use concept, where the setting and tourists have no defined roles, but interact together to co-create value (Vargo et al., 2008). As such, "marketing is moved from a 'market to' philosophy where tourists are promoted to, targeted, and captured, to a 'market with' philosophy where the tourist and setting are collaborators in the entire marketing process," (Cova \& Salle, 2008, p. 271).

In the hospitality and tourism industry, creating memorable experiences for customers by gener- ating co-creation of experiences is key. For example, Shaw et al. (2011) have used a series of case stud-ies to demonstrate the importance of the tourist as an operant. These studies were conducted in an attempt to see value co-creation in action as selected hotels placed Apple products in rooms to see how customers used them. In doing so, customers were informed that this offering was a trial and were asked for their feedback. This alone had the tourists involved in the process. However, in doing so, the hotels learned what guests would like to see, and how they could make the overall stay more interactive and beneficial for the guests, thus increasing their participation in co- $^{-}$ creation, which in turn served to enhance overall satisfaction (Shaw et al., 2011). This example provides a significant contribution to the literature by suggesting that hotels should implement co-creation of experiences with customers.

For tourists, service means that all resources and processes obtained from the setting are used in a service process, which may assist them in creating value from the service 
they obtain from the setting. A tourist views service as the ability to use a hotel room to their own discretion, and be able to come and go as they please. They might also make use of the front desk in order to obtain information about the local area or to ask for directions, which would make their stay easier and more valuable. For the setting, service means supporting the tourist as service providers using their resources to create value. As such, service providers should adopt an integrative service, encouraging interaction and participa- tion from both parties (Grönroos, 2011).

In summary, the purpose of co-creation of experiences is for value to be created for all stakeholders (depending who is involved). The goal is that the final service be valued more greatly after stakehold- ers have had the opportunity to add input and personal resources into the service.

\section{Can co-creation of an experience affect satisfaction with the vacation experience and perceptions of vacation on life overall}

Satisfaction is an important concept in tourism (e.g., Meng, Tepanon, \& Uysal, 2008; Oliver, 1980; Prayag \& Ryan, 2012). A number of studies show that understanding tourist satisfaction is essential to successful destination marketing because it not only impacts the consumption of goods and services, but also the future selection of a destination and intention to visit by tourists (e.g., Baloglu, Pekcan, Chen, \& Santos, 2004; Williams \& Soutar, 2009; Yoon \& Uysal, 2005). Furthermore, satisfaction is viewed as a result of service quality, destination image, motivation, and perceived value of vacation experience (e.g., Baker \& Crompton, 2000; Cronin, Brady, \& Hult, 2000; Prebensen et al., 2013).

However, there is, if any, limited empirical evidence that links tourists' co-creation of an experience and satisfaction with the vacation experience (Lee, 2012; Shaw et al., 2011). For example, Shaw et al. (2011) argue that participation in co-creation is likely to increase tourists' travel satisfaction. As participation in service recovery has been shown to improve a tourist's satisfaction with the recovery, it is hypothesized that tourist satisfaction may likewise result from greater participation in co-creation (Dong, Evans, \& Zou, 2008; Grissemann \& Stokburger-Sauer, 2012; Lee, 2012). Dong et al. (2008) used scenario-based role playing experiments on students to test their hypotheses on how customer involvement in service recovery affects satisfaction and how customer involvement helps clarify the customer's role in the co-creation process when dealing with service recovery. Another study by Bitner, Franda, Hubbert, and Zeithmal (1997) showed that customers have important roles to create service outcomes, thus, eventually increasing their own satisfaction.

Furthermore, satisfaction with a tourism experience can contribute to perceived overall life satis- faction. Recently, specific attention has been paid to tourism as a means of improving perception of life satisfaction (e.g., (Gilbert \& Abdullah, 2004; Kim, Woo, \& Usyal, 2015; Sirgy, Kruger, Lee, \& Yu, 2011; Uysal, Perdue, \& Sirgy, 2012). Several studies were able to demonstrate that tourism experiences have a positive influence on perceived overall life satisfaction (e.g., Neal, Uysal, \& Sirgy, 2007; Sirgy, 2010).

Subjective indicators of overall life satisfaction capture individual's perception and experience of their life overall. A measure of perceived life satisfaction involves the following question about global eval- uations of life: how satisfied are you with your life? According to Sirgy (2010), perceived life satisfac- tion reflects one's evaluation of life overall or life accomplishments against some standard. In this study, perceived overall life satisfaction is used to measure the quality of life or well-being of the tourists. The influence of satisfaction with a tourism experience on perceived life satisfaction is 
commonly explained by the bottom-up spillover theory stating that perceived overall life satisfaction is influ- enced by satisfaction within specific life domains (e.g., sense of wellbeing in various life domains such as family life, social life, leisure and recreation life, health life, work life, financial life, and travel life) (e.g., Kruger, 2012; Sirgy, 2012; Uysal et al., 2012). Feelings of well-being in these life domains, in turn, are influenced by satisfaction with tourism services. For example, Kim et al. (2015) showed that the satisfaction of senior tourists with their vacation experiences, influenced perception of leisure life sat- isfaction and overall quality of life after their travel. Sirgy et al. (2011) tested the theoretical model that links a travel trip and life satisfaction. The results showed that trip events, including sources of positive and negative, affect different domains (e.g., social life, family life, and arts \& culture) and play an important role in tourists' overall sense of well-being. Furthermore, studies related to value cre- ation and life satisfaction suggest that value creation is seen as "a process through which the user becomes better off in some respect or which increases customers' satisfaction and wellbeing" (Vargo et al., 2008). Perception of overall life satisfaction is not influenced by only monetary concerns, such as income and standards of living, but also by the environment, physical and mental health, edu- cation, recreation and leisure time, and social wellbeing (Sirgy et al., 2011). In this respect, if a tourist is able to effectively interact and work alongside a tourism service provider, then their satisfaction with the relationship is likely to be amplified, spilling over onto the tourist's satisfaction with the vacation experience, which in turn may influence the perception of overall life satisfaction. The present study focuses on how one's vacation experience and perception of overall life satisfaction was changed as a result of the most recent trip (having co-creation of an experience) within a year. Tourists' perceptions of the impact of the vacation on life overall were captured in terms of their short-term feelings after their trip.

Based on the preceding discussion, the following hypotheses will be tested:

Hypothesis 1. Satisfaction with co-creation of an experience is likely to have a positive predictive effect on satisfaction with the vacation experience.

Hypothesis 2. Satisfaction with the vacation experience is likely to have a positive predictive effect on satisfaction with perceived impact of the vacation on life overall.

How does tourist's satisfaction with co-creation of an experience influence their loyalty to the service provider?

Customer loyalty to a firm is traditionally viewed as the situation in which a customer generally buys the same manufacturer-originated product or service repeatedly over time rather than switching among multiple competitors within the category (Oliver, 1980). Viewed in that light, satisfaction is regarded to be an essential predictor of loyalty (e.g., Bigné, Sánchez, \& Sánchez, 2001; Yoon \& Uysal, 2005). Grissemann and Stokburger-Sauer (2012) hypothesized that "when tourists have the opportunity to co-create a travel package, they are more likely to re-purchase from the same company and recommend the company to others," (p. 1485). That is, tourism service providers have the ability to develop loyal customers if they provide their clients the opportunity to participate and become involved in the creation process. As such, tourists may appreciate the chance to provide their own ideas and feedback in the co-creation process. If the co-creation process results in customer satisfaction, tourists are likely to return to the same company. Based on the preceding discussion, the following hypothesis will be tested: 
Hypothesis 3. Satisfaction with co-creation of an experience is likely to have a positive predictive effect on customer loyalty.

How does customer involvement in the co-creation process influence the satisfaction effect on loyalty?

Involvement is regarded as a motivational variable reflecting the extent of personal relevance of the decision to the individual in terms of basic goals, values, and selfconcept (e.g., Richins \& Bloch, 1986; Zaichkowsky, 1994). Manfredo (1989) defines involvement as the degree of interest in an activity and the affective response associated with that interest. Clements and Josiam (1995) inves- tigated the association between the level of involvement and travel decision-making. The finding of the study revealed that individuals who have high levels of involvement tend to travel abroad more often compared to those individuals with low levels of involvement. This further supports the notion that involvement is one of the important predictors of travel decisions (Prebensen et al., 2013).

Caru and Cova (2007) argued that there are two ways in which tourists can become involved in the co-creation process: passively or actively (Baron \& Warnaby, 2011). Passive involvement refers to interactions that are generally controlled by the setting - the tourist provides some input to the overall experience such as visiting a theme park. On the other hand, active involvement allows the tourist to immerse themselves in the experience, taking on responsibility for every step in the process. For example, research by Lee (2012) and Grissemann and Stokburger-Sauer (2012) have shown that the degree of involvement influences the effects of organizational support on the tour- ist's satisfaction with the service provider, customer loyalty, and service expenditures. The construct of involvement in this study is conceptualized to be reflective of an enduring trait. Thus, the con- struct of involvement included such items as "I enjoy having a hands-on approach; I take my time to invest in my vacation; I conduct thorough research before; I like to be informed of what goes into my travel experience; and I like to be informed of what goes into my travel arrangements." As a result, the study assumes that the level of involvement has a moderating effect on the outcome of the co-creation of an experience such as customer loyalty. Thus, the following hypothesis will be tested:

Hypothesis 4. The relationship between satisfaction with the co-creation of an experience and loyalty to the service provider is moderated by the tourist's level of involvement. Specifically, the satisfaction effect on loyalty is likely to be amplified under high rather than low involvement conditions.

\section{Methodology}

\section{Sampling and data collection}

In this study, a survey was used as the data collection method. The survey questionnaire involved items measuring satisfaction with co-creation of an experience, satisfaction with the vacation experi- ence, satisfaction with impact of the vacation on overall life, loyalty to the service provider, and involvement. In addition, demographic and geographic background variables were captured in the questionnaire. The measurement scales and survey questionnaire were developed in several stages following the procedures recommended by Churchill (1979) and DeVellis, 2011. The scale development process began with a creation of items to measure the constructs under 
examination. Original items were adopted from past research and adjusted to the context of the current study. After generating a list of indicators, professional experts in quality of life research were asked to evaluate and add or delete valuable indicators in co-creation of an experience and other constructs used in this study. Content validity was further tested using a pilot study. The pilot survey questionnaire was distributed to an online undergraduate class as well as to colleagues and friends through a survey website. A total of 198 completed questionnaires were collected over a four-day time period. The questionnaire was completed by target respondents, and the survey included screening questions at the beginning of the survey. Participants were screened based on their age (18 years of age or older), having taken a leisure trip in the past year (three or more nights away from home), and having participated in some kind of organized activity during which they received help from a travel professional for some aspect of that activity.

After the completion of the pilot test, data were collected using an online survey design company, Survey Monkey (www.surveymonkey.com), over a period of one month in April 2013. An online panel survey was conducted through the company's website. The panel maintained with the company is representative of the US population and the panel was stratified based on selected screening questions to create a representative sample within the goal parameters of this study. The company e-mailed around 2000 letters to members of their panel inviting them to participate in the study in April of 2013. After five days, 1348 people responded to the survey, however only 263 questionnaires were usable having met all the screening criteria. The company sent 1500 additional invitations to more members of their panel. This last set of invitations resulted in 907 additional people responding, yielding 298 usable questionnaires that met all of the screening criteria. Combined, this study achieved a final count of 561 completed questionnaires.

\section{Testing for common method bias}

Common method bias was tested for given the way this study was crafted. Common method bias was evaluated using Harman's single factor test, which determines if the majority of the variance can be explained by a single factor. In the model, the variance of a single factor was $33.69 \%$ indicating there is no common method bias. However, it is agreed that the way the study was crafted could have gen- erated common method bias. Nonetheless, it appears that this was not to the extent that it would cause any problems since the variance of a single factor measurement was less than .50 (33.69\%).

\section{Measurement of constructs}

Based on the pilot study, the measurement items were subjected to reliability (internal consis- tency) and validity tests. As previously mentioned the latent constructs were operationalized using measurement items used in past research. To test scale dimensionality, an exploratory factor analysis with a principle component method was conducted for each construct.

To measure satisfaction with co-creation of an experience, seven items were used from past research by Cova et al. (2011), Lee (2012) and Vargo, Lusch, Akaka, and He (2009). The measurement items were: "Working alongside of a travel professional allowed me to have a greater social interaction, which I enjoyed," "I felt comfortable working with a travel professional during this activity," "The set- ting of the vacation environment allowed me to effectively collaborate with the travel professional," "My vacation 
experience was enhanced because of my participation in the activity," and "I felt confident in my ability to collaborate with the travel professional." Responses were captured using a five-point Likert-type scale ranging from "strongly agree" at the high end to "strongly disagree" at the low end. A reliability test produced an Alpha coefficient of .85 after deleting two items. The results of the principle component factor analysis showed one factor representing 69 percent of the explained variance. As a result, a total of five items were included in the final survey questionnaire.

Satisfaction with the vacation experience was measured using three items: "Was this vacation worth your time?", "Was this vacation worth your effort?", and "Overall, how satisfied were you with your vacation destination?" These scale items were adapted from Sirgy (2012), and Woo and Uysal (2013), and responses were captured using a five-point rating scale ranging from "definitely not worth it" (1) to "definitely well worth it" (5) and "not satisfied at all" (1) to "very satisfied" (5), respectively. The reliability of this satisfaction construct was acceptable (Alpha $=.82)$.

Satisfaction with impact of the vacation on life overall was measured using six items adapted from Neal, Sirgy, and Uysal (2004) and Neal et al. (2007). Example items include: "Overall, my experience with this vacation was memorable having enriched my quality of life," "My satisfaction with life in general was increased shortly after this vacation," and "All in all, I feel that this vacation has enriched my life. I'm really glad I went on this trip." Responses to these items were captured using a five-point Likert-type scale ranging from "strongly disagree" (1) to "strongly agree" (5). A reliability test produced an Alpha coefficient of .90.

Loyalty to the service provider was captured using three items based on past research (Huang \& Hsu, 2009; Um, Chon, \& Ro, 2006; Yoon \& Uysal, 2005). The items were: "I have a preference for a particular service provider", "I consider myself to be loyal to one service provider", and "I am satisfied with my service provider, so I do not wish to try a different one." The reliability of this construct yielded an Alpha coefficient of .85.

Lastly, the tourist's level of involvement was adapted and modified using items from Kyle, Absher, Hammitt, and Cavin (2006), Kyle and Chick (2004) and Prebensen et al. (2013). Example items are: "I enjoy having a hand on approach during my vacation experience," "I take my time to invest in my vacation experience," and "I conduct thorough research before going on a vacation." Responses to these items were captured using a five-point Likert-type scale ranging from "strongly disagree"

(1) to "strongly agree" (5). A reliability test of the involvement construct produced an Alpha coefficient of .87 (after deleting one item: "I am comfortable sharing ideas regarding my vacation expectations"). A total of five items were used to measure the involvement construct.

In sum, the measurement of the five constructs based on the pilot study showed strong reliability, and as such were included in the final survey. In addition, the reliability and uni-dimensionality of all of five constructs were also tested in final data set. The results are reported in the following section.

\section{Data analysis and results}

The study investigated the interrelationships between latent constructs of satisfaction with co-creation of an experience, satisfaction with the vacation experience, satisfaction with impact of the vacation on overall life and loyalty to the service provider as captured by the hypotheses. To test the proposed model, Structural Equation Modeling (SEM) was employed because SEM is effective in capturing interrelationships among 
latent constructs (Schreiber, Nora, Stage, Barlow, \& King, 2006). First, a Confirmatory Factor Analysis (CFA) was conducted to examine the interrelationships and covariance among all latent constructs to entertain the possibility that variables could be deleted based on the results of factor loadings and the modification index (Schreiber et al., 2006). In the structural model section, relationships among the latent constructs were tested through a series of structural equations. Therefore, SEM allowed the theoretical relationships between one exogenous variable (satisfaction with the co-creation of an experience), and three endogenous variables (satisfaction with the vacation experience, perceived impact of the vacation on overall life, and loyalty to the service provider) to be tested. The statistical tool AMOS 20.0 was used, specifically the maximum likelihood (ML) method of estimation.

Before conducting SEM analysis, several assumptions of SEM were checked. First, no missing data or significant outliers were found in the data. In addition, the normal distribution of the observed vari- ables was met based on the results of skewness and kurtosis. The result of the multivariate normality check showed that the relative multivariate kurtosis (1.351) was smaller than 2.0, which indicated that the distribution of all combinations of variables was normal. To ensure proper use of the maximum likelihood estimation (MLE), a representative sample of at least 300 cases was desired, which resulted in normally distributed data. Three hundred cases were desired as Hoelter (1983) recommends a sample size of 300 in SEM analysis; the sample size of 561 in this study was deemed sufficient for the planned data analysis. Because the company used for data collection maintains a panel data representative of the study population, the response rate was rather high, resulting in a relatively large sample of more than 500 returns.

\section{Demographic information}

The demographic profile of the sample is as follows. Of the 561 respondents, $56.1 \%$ (315) were male and $43.9 \%$ (246) were female. In terms of age, respondents between the ages of $18-29(16 \%), 30-44(20.3 \%), 45-60(36.9 \%)$, and 61 and over $(26.6 \%)$.

\section{Measurement model}

A CFA of the measurement model was performed to check whether the collected data fit the hypothesized measurement model (Hair, Black, Babin, \& Anderson, 2010). First, each construct in the model was tested separately before testing the measurement model overall. The results showed that the indicators of each latent construct exceeded the standard with an Alpha coefficient of .70. Jöreskog and Sörbom (1993) suggest that an indicator with an Alpha coefficient below 0.30 should not be included in the analysis. Therefore, no indicators within any of the constructs were deleted from this analysis.

A total of five exogenous variables and 12 endogenous variables were used in the overall measurement model. In testing the measurement model, the results showed the model to be a good fit: v2 $(113)=406.405(p<.000)$, CFI $=.95, \mathrm{NFI}=.94$, RMSEA $=.068$, and $\mathrm{RMR}=.030$. It should be noted,

however, that the significant $\mathrm{Chi}$-square may be attributed to the fact that large samples are likely to inflate the sensitiveness of Chi-square statistics in SEM (Satorra \& Bentler, 2001). In sum, the model fit indices showed that the data fit the hypothesized model well (see Table 1).

Regarding construct reliability, the reliability of the four constructs exceeded .70, ranging from .79 to .84 . The results of the standardized loadings showed that factor loadings were relatively high, and the t-value of each indicator was statistically 
significant, exceeding the critical level of 1.96 (Hatcher, 1994). Moreover, Average Variance Extracted (AVE) estimates of the four constructs exceeded the minimum criterion of .50 (Fornell \& Larcker, 1981). Discriminant validity was also tested by comparing the shared variance between each pair of constructs against the minimum of the AVEs for those constructs (Fornell \& Larcker, 1981). The results showed that the shared variance observed for each pair of constructs was lower than the minimum of their AVEs; therefore, discriminant validity was evidenced. Table 2 summarizes the results of the construct reliability and validity.

Table 1 here

Table 2 here

\section{Structural model}

The relationships between the latent constructs in the proposed model were tested by using SEM. Even though the Chi-square value (435.391, df = 116) was unacceptable, other goodness-of-fit indices met the requirements of good fit $[\mathrm{CFI}=.95$, RMSEA $=.070$, $\mathrm{NFI}=.93, \mathrm{RMR}=.056]$. Therefore, according to suggested goodness-of-fit indices, we conclude that the theoretical model is consistent with the observed data (see Fig. 1).

Figure 1 here

Table 3 here

Table 3 shows the results of the hypotheses testing. First, we hypothesized a positive relationship between satisfaction with co-creation of an experience, satisfaction with the vacation experience, and loyalty to the service provider. The results of the hypotheses testing revealed that satisfaction with co-creation of an experience positively affects satisfaction with the vacation experience and loyalty to the service provider providing support for Hypotheses 1 and 3. Furthermore, satisfaction with the vacation experience was shown to be a significant predictor of satisfaction with impact of the vacation on overall life, supporting Hypothesis 2.

\section{Moderating effect of level of involvement}

This stage of the data analysis focused on the tourist's level of involvement in the travel logistics as a moderator between satisfaction with co-creation of an experience and loyalty to the service provider (Hypothesis 4). It was hypothesized that involvement strengthens the relationship between satisfaction with co-creation of an experience and 
loyalty to the service provider. To test this moderating effect, the involvement variable was split into two groups (high and low involvement). The mean of the involvement variable was used to create the two groups-237 respondents had involvement scores below the mean (low involvement) and 324 had involvement scores above the mean (high involvement). The test of a Chi-square difference and critical ratio difference test was used in AMOS. The result of the Chi-squared comparison of unconstrained and constrained models suggested that the paths between the high and low involvement groups were significantly different (Dv2/Ddf. $=10.979(1), p<.00)$. Furthermore, a critical ratio for group differences in regres- sion weights showed that the level of involvement moderates the effect between satisfaction with co-creation of an experience and loyalty to the service provider such that the effect is stronger for those with high involvement $(b=.27 / /)$ than for those with low involvement $(b=.034)$. See Table 4 . Based on these results we conclude that the results of the moderating effect of involvement support Hypothesis 4 .

Table 4 here

\section{Discussion}

In this study we tested a model that proposed relationships among five constructs: satisfaction with co-creation of an experience, satisfaction with the vacation experience, perceived impact of the vacation on overall life, loyalty to the service provider, and customer involvement.

The findings of this study indicate that satisfaction with co-creation of an experience (i.e., tourists collaborating with a travel professional to provide their own ideas, and express their needs and desires to ensure that the trip is tailored to them personally) can contribute to satisfaction with the vacation experience. One may argue that this is not a new idea. However, given the nature of our screening questions and the way the construct of co-creation of an experience was worded, the study created a setting in which the respondent had the opportunity to engage meaningfully in the process of creating and shaping the nature of his or her experience. This finding is essentially consistent with past research (e.g., Grissemann \& Stokburger-Sauer, 2012; Lee, 2012). Moreover, the study confirms past research that demonstrates the link between satisfaction with the vacation experience and overall life satisfaction (e.g., Dong et al., 2008; Shaw et al., 2011). Satisfaction with the vacation experience helps improve a tourist's overall life satisfaction during a trip and after they return home. Thus, we argue that the findings of this study contribute to the growing body of knowledge in understanding the per- ceived value of tourism experiences by establishing a theorybased empirical link between satisfaction with co-creation of an experience and overall life satisfaction via travel satisfaction. This link had not been empirically demonstrated, as until this study, no study had focused on the aftereffects of partic- ipation in co- $^{-}$ creation of an experience. Also, this study provides much evidence for the moderating 
effect of involvement in strengthening the effect of satisfaction with co-creation of an experience and loyalty to the service provider.

With so many unknowns dealing with co-creation of an experience, it becomes hard for tourists to co-create and for travel professionals to create programs that include tourists in the value creation process. This study helps develop a deeper understanding of co- $^{-}$ creation and creating value in vacation experiences. Based on how we measured satisfaction with co-creation of experiences, we argue that co-creation of an experience can be based on:

- Enhanced tourist participation in the experience;

- The confidence of being able to open up to a travel professional and comfortably work alongside of them;

- An environment which facilitates the coming together of two or more parties to create a unique, personalized, value-added experience; and

- The opportunity for greater social interaction.

Co-creation, then, is no longer simply about a tourist becoming a co-creator of value with increased personalized attention that results in greater interactions. Co-creation of an experience should be expanded to include the co-production of new and improved services, with added value for both tour- ists and travel professionals. This comes about as a result of their trust in one another through coop- eration and collaboration in a setting which allows both parties to participate equally alongside of each other. As such, co-creation of an experience is always ongoing, adaptable, personalized, and unique.

From a managerial perspective, the study findings encourage service providers to reexamine how they can facilitate tourism experiences and the settings. Service providers can create programs to allow tourists to become more physically and emotionally engaged, thus encouraging co-creation of an experience. Service providers should communicate to tourists the message that tourists' ideas are sought and welcomed (Edvardsson \& Oskarsson, 2011). In order for a hospitality company to partake in the co-creation process they should clearly understand their role and be able to use the co-creation process effectively and efficiently in order to create financial value in the end. For example, hospitality firms could develop and initiate a customer information system (CIS) that would be con- ducive to the facilitation and co-creation of experiences. This system will gather data about guests and will allow the hotel to learn about what type of visitor a guest is, what amenities they enjoy, and what services they desire. Moreover, customer involvement as defined in the study was found to be a significant moderator influencing the effect of satisfaction of co-creation of an experience on loy- alty. This means that it is important for service providers to facilitate the extent to which their cus- tomers could have the opportunity to get involved in travel and tourism activities. As pointed out by Caru and Cova (2007), there are two ways in which customers can become involved in the co- creation process: passively or actively (Baron \& Warnaby, 2011).

However, this involvement would be better understood as a function of their personality and how this could be played in the experience sphere. In developing a platform for co- $^{-}$ creation, service provi- ders should be aware of the individual comfort level of each tourist, keep them informed of the process along the way, and adjust the environment accordingly. In other words, the service provider should gauge the desired level of 
involvement of their customers and focus more on customers who are more likely to get involved in different aspects of travel activities and logistics as greater benefits are to be expected. These customers are the ones that would likely remain loyal after they are satisfied with the co-creation of their experience. Thus, the more satisfied a tourist is with his or her co-creation of an experience and the more involved that person is with his or her travel activities, logistics, and arrange- ments, the more likely it is that he or she will return to the same service provider and recommend the service provider to others. Doing so should lead to increased profits for the service provider and help build a more loyal client base (Grissemann \& Stokburger-Sauer, 2012). Service providers that devise co-creation programs can gain a competitive advantage by inventing new methods of business which will generate more value as these strategies will be harder to imitate (Cova et al., 2011). In today's business environment, service providers should focus more on co-creating value through more per- sonalized products and services. Co-creation of an experience, as a business concept in travel and tour- ism, is likely to gain momentum in the years to come. As this study shows, co-creation of an experience is likely to result in a life-enriching and memorable vacation experience, contributing to one's sense of wellbeing.

\section{Study limitations and future research}

Co-creation of an experience is ongoing and adaptable, so while it is present during a particular activity, it can also continue throughout the tourist's entire vacation experience. Future research should expand the concept of co-creation of an experience to cover aspects related to experiences related to pre-trip, during, and post-trip. Another limitation of the study is the fact that co-creation of experiences was limited to experiences between tourists and service providers. There is also a need to consider other contexts of co-creation; for example, what about the co-creation of experiences among tourists? Future research should capture co-creation of experiences to cover all forms of co- creation among tourists and service providers. In today's technological age many tourists interact with friends and other tourists on the internet. The study is contextualized in the destination setting rather than the situation where purchasing travel and holiday services takes place online. Future studies need to consider $\mathrm{co}^{-}$ creation of an experience when purchasing travel and holiday services online. It is also important to mention that studies like this based survey inferences may not do much justice to the concepts of well-being and life satisfaction that have deep meanings in the minds of people and thus, such studies need to be augmented with qualitative and, or, mixed method designs in order to generate the much needed personal meanings and contextualization.

It is also important to note that given the heightened interest in more meaningful and life lasting experiences that today's consumers are looking for, we will see more research that would examine how experiences should be created and designed in order to meet not only basic needs but also appeal to evolving needs such as self-actualization, selfdevelopment and growth. While once a source of dis- sonance, today most destinations are capable of meeting the basic needs of travelers and tourists (such as comfort, ease of access, hygienic factors, physical conditions and the like). Therefore it is important to ask, what will destinations do in order to compete and also cater to the evolving needs of 
today's engaged and experiential travelers? Engaging in similar types of research to this study will certainly help destination promoters and service providers to be better prepared for the apparent change which can be seen within the market place.

\section{References}

Baker, D. A., \& Crompton, J. L. (2000). Quality, satisfaction and behavioral intentions. Annals of Tourism Research, 27(3), 786-804. Baron, S., \& Warnaby, G. (2011). Value cocreation from the consumer perspective. Boston, MA: Springer.

Baloglu, S., Pekcan, S., Chen, L., \& Santos, J. (2004). The relationship between destination derformance, overall satisfaction, and behavioral intention for distinct segments. Journal of Quality Assurance in Hospitality \& Tourism, 4(3-4), 149-165.

Bigné, J. E., Sánchez, M. L., \& Sánchez, J. (2001). Tourism image, evaluation variables and after purchase behaviour: Inter- relationship. Tourism Management, 22(6), 607-616.

Bitner, M. J., Franda, W. T., Hubbert, A. R., \& Zeithmal, V. A. (1997). Customer contributions and roles in service delivery.

International Journal of Service Industry Management, 8(3), 193-205.

Binkhorst, E., \& Dekker, T. D. (2009). Agenda for co-creation tourism experience research. Journal of Hospitality Marketing and Management, 18, 311-327.

Bjork, P., \& Sfandla, C. (2009). A tripartite model of tourist experience. Finnish Journal of Tourism, 5(2), 5-18. Caru, A., \& Cova, B. (2007). Consuming experience. New York, NY: Routledge.

Cabiddu, F., Lui, T., \& Piccoli, G. (2013). Managing value co-creation in the tourism industry. Annals of Tourism Research, 42, 86-107.

Cova, B., Dalli, D., \& Zwick, D. (2011). Critical perspectives on consumers' role as 'producers': Broadening the debate on value co- creation in marketing processes. Marketing Theory, 11(3), 231-241.

Cova, B., \& Salle, R. (2008). Marketing solutions in accordance with the S-D logic: Cocreating value with customer network actors. Industrial Marketing Management, 37(3), 270-277.

Cronin, J. J., Brady, M. K., \& Hult, G. T. M. (2000). Assessing the effects of quality, value, and customer satisfaction on consumer behavioral intentions in service environments. Journal of Retailing, 76(2), 193-218.

Clements, C. J., \& Josiam, B. M. (1995). Role of involvement in the travel decision. Journal of Vacation Marketing, 1(4), 337-348. Churchill, G. A. Jr, (1979). A paradigm for developing better measures of marketing constructs. Journal of marketing research, 64-73. 
Dong, B., Evans, K. R., \& Zou, S. (2008). The effects of customer participation in cocreated service recovery. Journal of the Academy of Marketing Science, 36(1), 123-137.

DeVellis, R. F. (2011). Scale development: Theory and applications (26). Sage Publications.

Edvardsson, I. R., \& Oskarsson, G. K. (2011). Knowledge management and value creation in service firms. Measuring Business Excellence, 15(4), 7-15.

Fornell, C., \& Larcker, D. (1981). Structural equation models with unobservable variables and measurement error. Journal of Marketing Research, 18(1), 39-50.

Grissemann, U. S., \& Stokburger-Sauer, N. E. (2012). Customer co-creation of travel services: The role of company support and customer satisfaction with the co-creation performance. Tourism Management, 33(6), 1483-1492.

Grönroos, C. (2011). Value co-creation in service logic: A critical analysis. Marketing Theory, 11(3), 279-301.

Gilbert, D., \& Abdullah, J. (2004). Holidaytaking and the sense of well-being. Annals of Tourism Research, 31(1), 103-121. Hair, J. F., Black, W. C., Babin, B. J., \& Anderson, R. E. (2010). Multivariate data analysis. New Jersy: Pearson Education.

Huang, S., \& Hsu, C. H. C. (2009). Travel motivation: Linking theory to practice. International Journal of Culture, Tourism and Hospitality Research, 3(4), 287-295.

Hatcher, L. (1994). A step-by-step approach to using the SAS(R) system for factor analysis and structural equation modeling. Cary, NC: SAS Institute.

Hoelter, J. (1983). The analysis of covariance structures: Goodness-of-fit indices. Sociological Methods and Research, 11, 325-344. Jöreskog, K. G., \& Sörbom, D. (1993). Lisrel 8: Structured equation modeling with the simplis command language. IL, USA: Scientific

Software International.

Kim, H., Woo, E., \& Usyal, M. (2015). Tourism experience and quality of life among elderly tourists. Tourism management, 46, 465-476.

Kristensson, P., Matthing, J., \& Johansson, N. (2008). Key strategies for the successful involvement of customers in the co- $^{-}$creation of new technology-based services. International Journal of Service Industry Management, 19(4), 474-491.

Kruger, P. S. (2012). Perceptions of tourism impacts and satisfaction with particular life domains. In M. Uysal et al. (Eds.),

Handbook of tourism and quality-of-life research: enhancing the lives of tourists and residents of host communities, international handbooks of quality-of-life (pp. 279-292). Dodrecht, Netherland: Springer.

Kyle, G. T., \& Chick, G. (2004). Enduring leisure involvement: the importance of personal relationships. Leisure Studies, 23(3), 243-266.

Kyle, G. T., Absher, J. D., Hammitt, W. E., \& Cavin, J. (2006). An examination of the motivation-involvement relationship. Leisure Sciences, 28(5), 467-485. 
Lee, G. (2012). Modeling consumer's co-creation in tourism innovation Ph.D. dissertation. Department of Philosophy, Temple University.

Meng, F., Tepanon, Y., \& Uysal, M. (2008). Measuring tourist satisfaction by attribute and motivation: The case of a nature-based resort. Journal of Vacation Marketing, 14(1), $41-56$.

Manfredo, M. J. (1989). An investigation of the basis for external information search in recreation and tourism. Leisure Sciences, 11(1), 29-45.

Neal, J. D., Sirgy, M. J., \& Uysal, M. (2004). Measuring the effect of tourism services on travelers' quality-of-life: Further validation. Social Indicators Research, 69(3), 243-249.

Neal, J. D., Uysal, M., \& Sirgy, M. J. (2007). The effect of tourism services on travelers' quality of life. Journal of Travel Research, 46

(2), 154-163.

Oliver, R. L. (1980). A cognitive model of the antecedents and consequences of satisfaction decisions. Journal of Marketing Research, 17(4), 460-469.

Prebensen, N., Vittersø, J., \& Dahl, T. I. (2013). Value co-creations significance of tourist resources. Annals of Tourism Research, 42, 240-261.

Prebensen, N., Chen, J. S., \& Uysal, M. (2014). Creating experience value in tourism. Boston: CAB International.

Payne, A. F., Storbacka, K., \& Frow, P. (2008). Managing the co-creation of value. Journal of the Academy of Marketing Science, 36

(1), 83-96.

Prayag, G., \& Ryan, C. (2012). Antecedents of tourists' loyalty to Mauritius: The role and influence of destination image, place attachment, personal involvement, and satisfaction. Journal of Travel Research, 51(3), 342-356.

Prebensen, N. K., Woo, E., Chen, J. S., \& Uysal, M. (2013). Motivation and involvement as antecedents of the perceived value of

the destination experience. Journal of Travel Research, 52(2), 253-264.

Prahalad, C. K., \& Ramaswamy, V. (2004). Co-creating unique value with customers. Strategy \& Leadership, 32(3), 4-9. Richins, M. L., \& Bloch, P. L. (1986). After the new wars off: the temporal context of product involvement. Journal of Consumer

Behavior, 13(2), 280-285.

Satorra, A., \& Bentler, P. M. (2001). A scaled difference chi-square test statistic for moment structure analysis. Psychometrika, 66

(4), 507-514.

Schreiber, J. B., Nora, A., Stage, F. K., Barlow, E. A., \& King, J. (2006). Reporting structural equation modeling and confirmatory factor analysis results: A review. The Journal of Educational Research, 99(6), 323-337. 
Shaw, G., Bailey, A., \& Williams, A. (2011). Aspects of service-dominant logic and its implications for tourism management: Examples from the hotel industry. Tourism management, 32(2), 207-214.

Sirgy, M. J., Kruger, P. S., Lee, D., \& Yu, G. (2011). How does a travel trip affect tourists' life satisfaction? Journal of Travel Research, 50(3), 261-275.

Sirgy, M. J. (2010). Toward a quality-of-life theory of leisure travel satisfaction. Journal of Travel Research, 49(2), 246-260. Sirgy, M. J. (2012). The psychology of quality of life. Dordrecht, Netherlands: Springer.

Um, S., Chon, K., \& Ro, Y. (2006). Antecedents of revisit intention. Annals of Tourism Research, 33(4), 1141-1158.

Uysal, M., Perdue, R., \& Sirgy, M. J. (2012). Handbook of tourism and quality-of-life research: Enhancing the lives of tourists and residents of host communities. Dodrecht, Netherland: Springer.

Vargo, S. L., Lusch, R. F., Akaka, M. A., \& He, Y. (2009). Service-dominant logic. Review of Marketing Research, 6(1), 125-167. Vargo, S. L., Maglio, P. P., \& Akaka, M. A. (2008). On value and value co-creation: A service systems and service logic perspective.

European Management Journal, 26(30), 145-152.

Vargo, S. L., \& Lusch, R. F. (2008). Service-dominant logic: Continuing the evolution. Journal of the Academy of Marketing Science, 36(1), 1-10.

Verhoef, P., Reinartz, W. J., \& Krafft, M. (2010). Customer engagement as a new perspective in customer management. Journal of Service Research, 13(3), 247-252.

Walls, A. R., \& Wang, Y. (2001). Experiential consumption and destination marketing. Wallingford, UK: CAB International. Williams, P., \& Soutar, G. N. (2009). Value, satisfaction and behavioral intentions in an adventure tourism context. Annals of Tourism Research, 36(3), 413-438.

Woo, E., \& Uysal, M. (2013). Quality of life based on motivation, perceived value of destination experience, and satisfaction. In Paper presented at the the 18th annual graduate education and graduate student research conference in hospitality and tourism. Seattle, WA.

Yoon, Y., \& Uysal, M. (2005). An examination of the effects of motivation and satisfaction on destination loyalty: a structural model. Tourism Management, 26(1), 45-56.

Zhang, X., \& Chen, R. (2008). Examining the mechanism of the value co-creation with customers. International Journal of Production Economics, 116(2), 242-250.

Zaichkowsky, J. L. (1994). Research note: the personal involvement inventory: Reduction, revision, and application to advertising. Journal of Advertising, 23(4), 59-70. 
Table 1

Goodness-of-Fit Indices $(N=561$.

\begin{tabular}{|c|c|c|c|c|c|c|c|c|}
\hline \multirow[t]{2}{*}{$x^{2}$} & \multirow[t]{2}{*}{ df } & \multicolumn{2}{|c|}{$\begin{array}{l}\text { Absolute fit } \\
\text { measures }\end{array}$} & \multirow{2}{*}{$\begin{array}{l}\text { Incremental fit measures } \\
\mathrm{NFI}\end{array}$} & \multicolumn{4}{|c|}{ Parsimonious fit measures } \\
\hline & & RMR & RMSEA & & PNFI & $\mathrm{CFl}$ & IFI & RFI \\
\hline $406.405(p=.0)$ & 113 & .030 & .068 & .94 & .78 & .95 & .95 & .92 \\
\hline
\end{tabular}


Table 2

CFA results of the overall measurement model $(N=561)$.

\begin{tabular}{|c|c|c|c|}
\hline Constructs and indicators & $\begin{array}{l}\text { Standardized } \\
\text { loading (Li) }\end{array}$ & $\begin{array}{l}\text { Reliability } \\
\left(\mathrm{Li}^{2}\right)\end{array}$ & $\begin{array}{l}\text { Error variance } \\
\text { extracted }\end{array}$ \\
\hline Co-creation of experience & & $.79^{*}$ & $.61^{* * k}$ \\
\hline $\begin{array}{l}\text { Working alongside of a travel professional allowed me to have a } \\
\text { greater social interaction, which I enjoyed }\end{array}$ & .72 & .52 & .48 \\
\hline $\begin{array}{l}\text { I felt comfortable working with a travel professional during this } \\
\text { activity }\end{array}$ & .84 & .71 & .29 \\
\hline $\begin{array}{l}\text { The setting of the vacation environment allowed me to effectively } \\
\text { collaborate with the travel professional }\end{array}$ & .80 & .64 & .36 \\
\hline $\begin{array}{l}\text { My vacation experience was enhanced because of my participation in } \\
\text { the activity }\end{array}$ & .68 & .46 & .54 \\
\hline I felt confident in my ability to collaborate with the travel professional & .86 & .74 & .26 \\
\hline Satisfaction with vacation experience & & $.82^{*}$ & $.74^{* k}$ \\
\hline Was this vacation worth your time? & .96 & .92 & .08 \\
\hline Was this vacation worth your effort? & .93 & .86 & .14 \\
\hline Overall, how satisfied were you with your vacation destination? & .66 & .44 & .56 \\
\hline Satisfaction with impact of vacation on overall life & & $.82^{*}$ & $.63^{* *}$ \\
\hline $\begin{array}{l}\text { All in all, I feel that this vacation has enriched my life. I'm really glad I } \\
\text { went on this trip. }\end{array}$ & .84 & .71 & .29 \\
\hline $\begin{array}{l}\text { On this trip, I accomplished the purpose of the vacation. This } \\
\text { experience has enriched me in some ways }\end{array}$ & .84 & .71 & .29 \\
\hline $\begin{array}{l}\text { This vacation was rewarding to me in many ways, I feel much better } \\
\text { about things and myself after this trip }\end{array}$ & .82 & .67 & .33 \\
\hline $\begin{array}{l}\text { Overall, my experience with this vacation was memorable having } \\
\text { enriched my quality of life }\end{array}$ & .84 & .71 & .29 \\
\hline $\begin{array}{l}\text { My satisfaction with life in general was increased shortly after this } \\
\text { vacation }\end{array}$ & .70 & .49 & .51 \\
\hline Overall, I felt happy upon my return from this vacation & .70 & .49 & .51 \\
\hline Loyalty to service provider & & .84 & $.75^{* *}$ \\
\hline I have a preference for a particular service provider & .87 & .76 & .24 \\
\hline I consider myself to be loyal to one service provider & .96 & .92 & .08 \\
\hline $\begin{array}{l}\text { I am satisfied with my service provider, so I do not wish to try a } \\
\text { different one }\end{array}$ & .76 & .58 & .42 \\
\hline
\end{tabular}

${ }^{*}$ Composite reliability.

${ }^{* *}$ Average Variance Extracted (AVE) estimate. 

Table 3

Results of the proposed model.

\begin{tabular}{llc}
\hline Hypothesized path & $\begin{array}{l}\text { Standardized } \\
\text { coefficients }\end{array}$ & $t$-Value \\
\hline $\begin{array}{l}\text { H1: Satisfaction with co-creation of experience } \rightarrow \text { satisfaction with vacation } \\
\quad \text { experience }\end{array}$ & .182 & $4.01^{* *}$ \\
$\begin{array}{l}\text { H2: Satisfaction with vacation experience } \rightarrow \text { satisfaction with impact of } \\
\quad \text { vacation on overall life }\end{array}$ & .493 & $11.53^{* *}$ \\
H3: Satisfaction with co-creation of experience $\rightarrow$ loyalty to service provider & .178 & $3.90^{* *}$ \\
\hline$* p<.001$. & &
\end{tabular}


Table 4

Results of the invariance test for the path (low vs. high involvement).

\begin{tabular}{|c|c|c|c|}
\hline & \multicolumn{2}{|c|}{$\begin{array}{l}\text { Standard path } \\
\text { coefficient }\end{array}$} & \multirow[t]{2}{*}{$\begin{array}{l}\chi^{2}(\mathrm{df}) \\
\text { difference }\end{array}$} \\
\hline & $\begin{array}{l}\text { Low } \\
\text { level }\end{array}$ & $\begin{array}{l}\text { High } \\
\text { level }\end{array}$ & \\
\hline $\begin{array}{l}\text { Satisfaction with co-creation of experience } \rightarrow \text { satisfaction with vacation } \\
\text { experience } \\
\text { Overall model fit } \chi^{2}(148)=358.86, \mathrm{CFI}=.95, \mathrm{NFI}=.91, \text { RMSEA }=.05\end{array}$ & .034 & $.27^{* *}$ & $10.979(1)^{* *}$ \\
\hline
\end{tabular}

${ }^{\prime} p<.001$. 


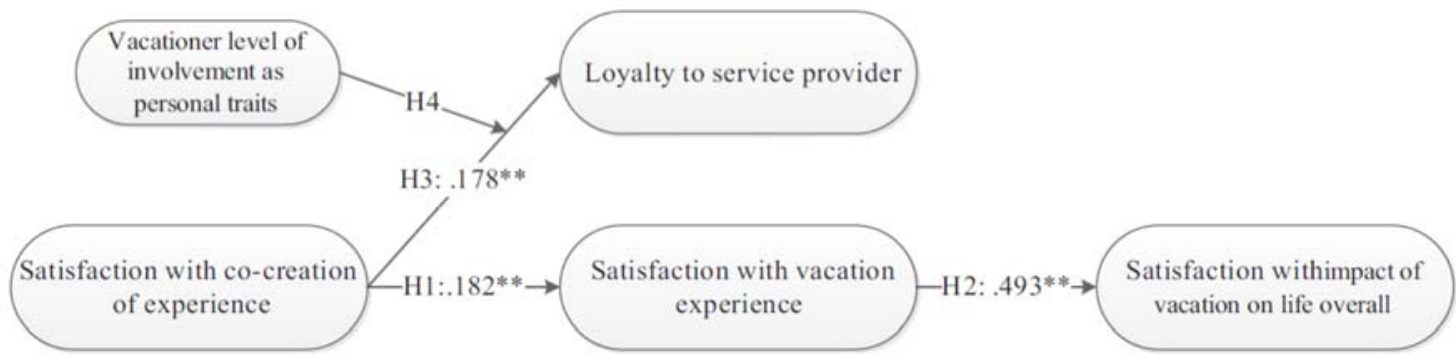

Fig. 1. Theoretical model. hypotheses and results. Note: $p<.001^{* *}$. 